American Journal of Economics and Business Administration 3 (2): 234-246, 2011

ISSN 1945-5488

(C) 2011 Science Publications

\title{
Diversification and Performance of Group-Affiliated Firms during Institutional Transitions: The Case of the Chinese Textile Industry
}

\author{
Qiang Zhang \\ Department of Social Systems and Management, \\ Graduate School of Systems and Information Engineering, \\ University of Tsukuba, 1-1-1 Tennodai, Tsukuba, Ibaraki, 305-8573 Japan
}

\begin{abstract}
Problem statement: Business groups play significant roles and evolve with the changing institutional environments in many emerging Asian economies. A study of how the institutional transition and the resultant 'institutionally rooted evolution' of business groups affect the diversification outcomes of affiliated firms will therefore help to deepen our understanding of this unique organizational form. Approach: This study uses the 2001-2005 data on listed firms from the Chinese textile industry and estimates the diversification effects of all firms in the sample and the differences in the diversification effects between group-affiliated firms and their stand-alone counterparts. Results: A positive relationship is found between the listed textile firms' unrelated diversification and their firm value during the period 2001-2005. Furthermore, the results indicate that group affiliation has complicated impacts on the diversification-performance relationship of the listed firms. Although group-affiliated firms are more successful in pursuing unrelated diversification when compared with stand-alone firms, such a difference in performance outcomes is statistically weak (as measured by Tobin's Q). Furthermore, it is found that group-affiliated firms perform related diversification worse than their stand-alone counterparts (as measured by both ROA and Tobin's Q). Conclusion: At late stages of the institutional transition, as in China at present, the dominant influence of institutional environments on the diversification-performance link of firms still works and motivates business groups to evolve organizationally. Such an organizational evolution has complex implications for group-affiliated firms' diversification: the weak performance advantage from unrelated diversification suggests that business groups' organizational evolution may contribute to the persistence of the comparative strength of business groups' internal markets; the concurrent low outcomes from related diversification however suggests that the organizational evolution disrupts the interrelations inside the group unavoidably and therefore hurts the fundamental foundation for the realization of related diversification's value-creation tendency.
\end{abstract}

Key words: Diversification, business group affiliation, institutional transitions, China's emerging economy, Related Party Transactions (RPTs)

\section{INTRODUCTION}

Given the significance of business groups in emerging Asian economies (Carney, 2008), in recent years, there has been an increasing concern about the relationship between group-affiliated firms' diversification strategies and their economic performance in the areas of management (Chakrabarti et al., 2007; Kim et al., 2004b; Singh et al., 2007) and corporate finance (Khanna and Palepu, 2000; Lins and Servaes, 2002).

In emerging Asian economies, group affiliation has often been found to be profitable (Carney, 2008;
Khanna and Yafeh, 2007). Under such circumstances, group affiliation may benefit firms by providing access to scarce resources embedded in institutional environments (Granovetter, 1995) via the internally built markets that substitute for the imperfect external product, capital and labor markets (Chang and Choi, 1988; Khanna and Palepu, 2000). Therefore, if a groupaffiliated firm can access the substantial group resources and use them to fuel its diversification strategy, a higher-performance effect of diversification should be possible (Chakrabarti et al., 2007).

Unfortunately, the empirical studies have yielded mixed or even contrasting results (Chakrabarti et al., 
2007; Lins and Servaes, 2002; Singh et al., 2007). Such an inconsistency suggests that the relationship between a group-affiliated firm's diversification and performance may be contingent on some influential factors, both inside and outside the business group. Existing studies have offered some complementary explanations with a focus on two primary issues: the impact of group internal organization and the dominant (direct) influences from institutional transitions.

The first issue is about group internal organization. Obviously, conventional strategic and organizational issues concerning the strategy-structure relationship (Chandler, 1962) and power dependency (Kim et al., 2004a) do still matter. Hence the organizational structure that the business group adopts (Khanna and Palepu, 2000) and the power position that an affiliated firm possesses in the business group (Kim et al., 2004a) will affect the 'optimal' strategy set of diversification that an affiliated firm can choose and consequently the expected performance effect.

However, more importantly, as the extent of both external resource acquisition and internal market building will be affected greatly by the fundamental changes of institutional environments (in other words, the institutional transition), the effects of the institutional transition will dominate. It is argued that when the institutional foundations of the emerging economy are moving toward markets, business groups will be confronted with less accessibility to external institutional resources (Peng, 2003) and increasing institutional pressure (Kedia et al., 2006; Kim et al., 2004b). These external changes will result in necessary adaptations to be conducted at all levels of the business group, which increase the complexity of the strategy space that affiliated firms can choose when pursuing diversification strategies (Kedia et al., 2006; Lee et al., 2008).

In this study, however, we place more focus on the possibility that business groups evolve organizationally in response to the institutional pressure and on the implications for the diversification-performance relationship of affiliated firms. As argued in Carney (2008), business groups in emerging Asian economies are found to have coped with institutional transitions successfully, by actively renewing their internal institutional foundations, norms, or even their organizational structures. Such an 'institutionally rooted organizational evolution' will also, of course, affect the diversification-performance link of affiliated firms as it changes both the allocation of resources and the power relationships inside the business group (Meyer and Lu, 2005), but this has seldom been discussed in existing studies.
The aim of our study is therefore twofold: first, to ascertain the validity of the various arguments in previous institution-based studies of business groups and diversification by addressing a unique institutional setting; and second, to ascertain whether the institutionally rooted organizational evolution of business groups is meaningful for explaining the complexity of the diversification-performance link of group-affiliated firms.

The difficulty in the analysis of the diversificationperformance link of group-affiliated firms is caused primarily by its institutionally contextualized tendency and this raises specific requirements for more delicate institutional settings. We accomplish this by using 2001-2005 data on listed firms from the textile industry of China for the empirical analysis. The country environment and industry background offer a unique institutional setting to conduct a holistic study. Furthermore, the unique relationship between Chinese business groups and their listed affiliates is thought to be suitable for delineating the complexity when the two issues of institutional transition and group internal organization are considered simultaneously (Lee et al., 2008; Meyer and Lu, 2005).

Group internal organization: To explain what 'obstructs' affiliated firms from the use of group internal markets, some researchers have chosen to rely primarily on conventional strategic and organizational considerations, such as strategy-structure conflict as in Chandler (1962), power dependency and social network views.

The organizational structure of the business group affects the 'optimal' patterns of diversification strategy that affiliated firms should adopt and therefore the performance effect ultimately. For example, for widely diversified large business groups (often comprised of many affiliates), which are believed to be highly comparable with M-structure conglomerates in developed economies, a suitable strategy choice may be a combination of unrelated diversification at the group level and related diversification at the affiliate level (Khanna and Palepu, 2000). In this sense, related diversification is preferable to unrelated diversification at the affiliate level. However, for business groups that are less diversified or relatively small and therefore most probably with core affiliates, the circumstances will be more complicated. Compared with noncore affiliates in the group, core affiliates are considered to bear responsibility for conducting unrelated diversification on behalf of the whole group. As the access of individual affiliates to group internal resources is power dependent (Kim et al., 2004a), core 
affiliates may enjoy the preferential use of group resources, thereby acquiring the potential to pursue unrelated diversification more successfully. However, the drawback of these considerations is obvious; that is, the dominant roles of institutional environments in shaping the strategy pattern and structure of organizations are not addressed adequately.

Influence of institutional transitions: A dominant theoretic strand in business group study is that the benefits of group affiliation arise, at least partly, from the affiliated firms' access to 'extra' (or 'institutional') resources embedded in institutional environments (Granovetter, 1995) via group internal markets, while external market conditions are still imperfect and institutional foundations remain inadequate (Khanna and Yafeh, 2007). Therefore, it is very natural that researchers have begun to study differences in diversification strategy outcomes across different stages of institutional transition (Kedia et al., 2006; Kim et al., 2004b; Lee et al., 2008).

In emerging economies that undergo institutional transitions toward market economies, the aggregate level of institutional resources embedded in institutional environments tends to decline temporarily (Peng, 2003). Generally, such a general declining trend in the supply of 'extra' institutional resources will have a negative (but moderate) impact on the diversification effect of group-affiliated firms: if there used to be a diversification premium, then there tends to be a reduction in the diversification premium over time, but not a sudden diversification discount. The reason is that, especially in emerging Asian economies where institutional transitions are usually carried out in a gradual way, business groups possess considerable autonomy to respond to the institutional transition by changing the strategy patterns at group and affiliate levels (Kedia et al., 2006; Peng, 2003). This means that the 'optimal' diversification strategy set of groupaffiliated firms is also stage dependent. For example, in a historical study of the strategic changes in Indian business groups before and after 1991, Kedia et al. (2006) argue that for Indian business groups, unrelated diversification in the prereform era and related diversification in the reform era are the suitable strategy types for responding to the institutional transition. Although Kedia et al. (2006) focus on diversification strategy at the group level, such arguments should also apply to core affiliates to a large extent.

Therefore, when the institutional environments are changing, the diversification outcome will rely partly on affiliated firms' capabilities to behave adaptively. However, there exist problems because of the cognitive difficulty in understanding changes in institutional conditions (Peng, 2003), or because of inertia meaning that firms refuse to accept changes (Lee et al., 2008). Under such circumstances, there even arises the risk of overdiversifying into unrelated businesses that cannot be supported by the group resources; consequently, the decline in the diversification premium will be accelerated or will eventually turn into a diversification discount (Lee et al., 2008).

Institutionally rooted organizational evolution: Previous studies have suggested that for groupaffiliated firms, their diversification-performance link will be impacted (directly) by both group internal organization and institutional transitions. However, few of them have considered the possibility that the effects of the two variables may interact, although there has been some empirical evidence implying such a possibility (Carney, 2008).

Institutionally, the market orientation of institutional transitions in emerging economies not only determines the relative strength of various business organizational forms but also determines the tendency of strategies by which they compete with each other. Accordingly, business groups' adaptation to institutional transition should consist of two kinds of strategies as responses to the changes in both institutional and market environments: firstly and fundamentally, renew the underlying institutional forms and mechanisms (e.g., corporate governance, cultural values) to make them comparable with other business organizational forms; second, on that base, adjust the pattern of strategies such as diversification (Kedia et al., 2006) and organizational structure (Kim et al., 2004b). Meanwhile, previous studies have paid little attention to the first kind of strategy, which can be named 'institutionally rooted organizational evolution' from an institutional and organizational perspective.

In the real world, business groups are confronted with the difficulty of finding a balance point to pursue the two interrelated strategies properly. Of course, the extent of the difficulty is considered to be institutionally contextualized; for example, in a middle-level industrialized economy like Korea during 1990s, the influence of organizational evolution was considered to be relatively small as argued in Chang (2006) because the Korean business group is 'merely a general form of a diversified corporation'. Other studies have presented some similar opinions (Chang and Hong, 2000; Lee et al., 2008; Kim et al., 2004b). In a historical study of large Korean business groups, Kim et al. (2004b) argue that the constraints imposed by the organizational structure are a key determinant of the diversification 
effect of Korean business groups, but they do not mention the possible changes of institutional forms, including mechanisms inside the business group. Lee et al. (2008) report a negative impact of diversification on the performance of large Korean business groups during the mid 1990s and they conclude that the cause is over-diversification into unrelated industries but also that this is fundamentally a result of 'organizational inertia'. However, such an explanation in terms of inertia is too general, even ambiguous.

To deepen our understanding of the organizational aspects of affiliated firms' diversification, we turn to the Chinese context, where systematic existence of such an institutionally rooted organizational evolution has been observed widely.

Institutional settings of the study: We employ data on domestic listed firms from China's textile industry for the period 2001-2005. China offers a suitable country specificity to conduct a holistic study. First, China is known for its successful implementation of an incremental institutional reform during the last three decades. Such a gradual transition characteristic conforms to the common presumption underneath institution-based studies of business groups and diversification. They argue that as a general trend, the institutional transition in the emerging economy should be shifted in a market direction (Carney, 2008). On this basis, business groups are considered to have constrained autonomy to coevolve with the changing institutional environments (Carney, 2008; Kedia et al., 2006). These arguments will be significant most likely under circumstances of gradual institutional transitions but will be less relevant when institutional environments change radically.

Second, there is a well-observed coevolutionary relationship between Chinese business groups and the institutional environments (Carney et al., 2009). There is little debate on the timing of China's institutional transition: generally, researchers use 1993, the year when China enacted its first corporate law, to divide the institutional transition into the 'prereform era' and the 'reform era' (Aivazian et al., 2005; Meyer and Lu, 2005); more specifically, since 2000 when the modern enterprise system was established nationwide, China is considered to have entered its 'postreform era' (Lu and Yao, 2006).

Chinese business groups have exhibited significant homogeneity in their responses to institutional changes, which is helpful in identifying the systematic distinctions in strategic and organizational patterns across different institutional stages. Starting at the end of the 1970s when China was still a planned economy,
Chinese business groups have experienced continuous institutional evolution: From establishing independent legal status during the 1980s (Meyer and Lu, 2005), to corporatization (or controlled privatization) throughout the 1990s (Aivazian et al., 2005) and most recently, the 'partial listing' of Chinese business groups since the late 1990s (Lin and Su, 2008; Meyer and Lu, 2005).

Finally, partial listing is considered to be a new institutional strategy for Chinese business groups in the postreform era, to accelerate an evolution toward "merely a general form of diversified corporation" (Chang, 2006). Chinese business groups seldom go completely public in one round; instead, they take a gradual approach. This evolutionary process often begins with the listing of a core affiliate (usually one that has been corporatized fully, thereby being institutionally advanced), followed by a series of complicated institutional, organizational and strategic adjustments during a considerably long period (Meyer and Lu, 2005). Such an 'evolution after partial listing' can be understood as institutionally rooted organizational evolution in the Chinese context. Therefore, examining the unique characteristics of listed affiliated firms' diversification during the group evolutionary process will help to delineate the complexity when the interaction effects of institutional transitions and group internal organization are considered.

Regarding industry background, the Chinese textile industry became the largest textile industry in the world in 1994 and is considered as a highly unregulated industry in the Chinese economy. Although market competition has been the major force within the industry, business groups still possess significant influence. This industry setting, especially the market structure of the industry, is meaningful as our primary interest is the impact of group affiliation on firms' strategy outcomes during the market-orientated institutional transition.

Hypotheses: Because of the institutional contexts mentioned above, the listed affiliated firms are thought to possess relatively strong positions in Chinese business groups (Lu and Yao, 2006); in other words, they are core affiliates as discussed in previous studies (e.g., Kim et al., 2004a). Therefore, taking an institution-based view, we focus on (1) the impact of the institutional transition on the diversificationperformance relationship (of both group-affiliated firms and stand-alone firms) in the Chinese context and (2) the impact of the 'evolution after partial listing' on group-affiliated firms' diversification effect. One point worth mentioning is that, the predictions associated 
with our hypotheses have also taken into consideration the arguments about organizational structure and internal power dependency (Kim et al., 2004a) by addressing the characteristic of the listed affiliated firms as 'cores' in the Chinese business groups.

Diversification effects in the postreform era of China: Institution-based diversification theories argue that institutional environments determine the diversification pattern that firms can take. Therefore, not only the level of diversification but also the type of diversification is important (Kedia et al., 2006; Kim et al., 2004b). Different types of diversification vary in their strategic tendencies and economic potential: unrelated diversification is used mainly to utilize the internal capital market, whereas related diversification is believed to be more efficiency relevant as its economic rationalities lie in the economies of scope and vertical integration (Rumelt, 1986; Williamson, 1983).

When discussing the dominant influence of institutional environments, previous studies tend to rely on the relationship between unrelated diversification and firm performance. They examine differences in the performance effect of unrelated diversification at different stages of institutional transition, to evidence the extent to which the institutional resources embedded in institutional environments have changed (Lee et al., 2008). At this stage, the role of group affiliation (furthermore, strategic and organizational responses by business groups) is assumed away. Similarly, our analysis begins by addressing the extent to which the influence of institutional environments dominates in China during its postreform era.

Employing a sample of 816 listed firms from 74 two-digit industries in China during the period 20002002, Lin and Su (2008) report a significant positive effect of diversification on firm value (measured by Tobin's Q) and the result is robust to the use of alternative diversification measures such as the number of segments, Herfindahl index or dummy measures. They argue that the positive relationship between diversification and firm value implies that diversified firms may benefit relatively easily from their internal capital markets in China, 'where it is costly or impossible to raise external capital.' The sample composition (firms listed on the Shanghai or Shenzhen Stock Exchange) and the period covered (during the postreform era, after 2000) in our study and Lin and Su (2008) are highly comparable. Therefore, we have no reason to believe there exist characteristics of the textile industry, a traditional and significant industry in China's transition economy, that will change the causal relationship completely. Thus, we propose the first hypothesis as follows.
H1: In the Chinese textile industry during the postreform era, there is a positive association between unrelated diversification and firm performance.

Institutional transition and evolution after partial

listing: We now consider the main problem of the effect of simultaneous institutional transitions and internal organizational evolution of business groups. We delineate this issue by linking the diversificationperformance relationship to the 'evolution after partial listing' phenomenon of Chinese business groups.

As mentioned before, the evolution after partial listing is rooted institutionally in the history of China's institutional transition. After almost two decades of continuous institutional transformation since the end of the 1970s, China has established a market-oriented institutional system in which business organizations become more and more competitive on the basis of market mechanisms (Aivazian et al., 2005). The changes in institutional environments impose increasing pressure on Chinese business groups. Compared with the newly established independent firms and those former state-owned enterprises that may have undergone organizational transformations already, business groups have to make more effort to upgrade their internal institutions (e.g., the structure of property rights) at least to the average level of the industry. Such a disadvantageous position is, as argued in Meyer and $\mathrm{Lu}$ (2005), partly because of the relatively large scale and complex organizational contexts of Chinese business groups as loose hierarchical systems embedded with individual affiliates that vary in institutional tendencies and resource endowments.

Business groups evolve to reduce the evolutionary gaps; partial listing is the starting point of the evolutionary process. By transferring and integrating its 'most evolved' institutional forms and 'best' resources into listed affiliates, the business group may expect to create a virtuous cycle: successful implementation of the transfer-and-integrate procedure leads to both continuous spillover of advanced institutional practices and norms from listed affiliates to others and an increase in the business group's resource stock, which in turn stimulate new rounds of transfer-and-integrate. However, as the procedure will lead to unavoidable disruption and damage to the established interrelations (both technological and organizational) inside the business group, there arise costs or even failure risks if business groups cannot realize the complexity of the evolutionary process and fail to recover the broken interrelations in time.

The evolutionary process therefore tends to exert influence on unrelated and related diversification 
Am. J. of Economics and Business Administration 3 (2): 234-246, 2011

through different mechanisms: for related diversification, the influence will be direct and strong as it is considered to be interwoven with the evolutionary process; for unrelated diversification, the changes in the business group internal capital market caused by the evolutionary process will be meaningful. Theoretically, the influence of business groups' evolution should be reflected in the differences in the diversifications effect between group-affiliated firms and their stand-alone counterparts.

Unrelated diversification: Generally, previous studies argue that at the late stage of institutional transition such as the postreform era of China, significant improvement of external markets will result in reductions of both institutional resources embedded in institutional environments and the effectiveness of internal capital markets in business groups; for example, in the Chinese context, Carney et al., (2009) examine the effect of group affiliation on firm profitability (ROA) for 1997 and 2004 and find the effect disappeared in 2004. As the result, the positive effect of unrelated diversification tends to be decreasing temporally (Kedia et al., 2006; Lee et al., 2008).

Evolution after partial listing may ease such a decrease in the diversification premium. During the continuous self-evolving process toward 'a general form of diversified corporation' (Chang, 2006), if the business group can always find the balance point correctly, that is, to make the business group internal capital market with a lower limit no worse than standalone diversified firms, then the performance effect that group-affiliated listed firms can achieve from unrelated diversification would not be worse than what standalone firms can achieve.

Obviously, such an ideal scenario will rely heavily on business groups' capability to evolve, specifically, to balance within an acceptable range the potential longterm gains from evolution with the short-term loss. As we have discussed above, it is not an easy task. Therefore, considering the strategic complexity and individual variance in business groups' capability, we argue that the probability that group-affiliated firms systematically perform unrelated diversification better than their stand-alone counterparts is not high (meanwhile, the probability that group-affiliated firms systematically perform unrelated diversification worse is lower as such a scene seems more likely to appear when business groups undertake the evolutionary procedure radically). Thus, on the basis of Hypothesis 1 , which confirms the relationship between unrelated diversification and affiliated firms' performance, we add the second hypothesis as follows.
H2: In the Chinese textile industry during the postreform era, group affiliation does not affect significantly the relationship between unrelated diversification and firm performance.

Related diversification: Related diversification theory suggests that there should be a positive correlation between related diversification and firm performance (Rumelt, 1986). Recent studies further argue that to realize such a value-creation tendency, the firm needs to meet organizational requirements such as high coordination and interrelation to share resources and transfer skills across divisions (Kim et al., 2004b) and similarities in organizational, institutional and capability characteristics among segments (Farjoun, 1998). In other words, related diversification is a significantly organization-dependent issue.

Under the institutional setting of evolution after partial listing, listed affiliates' related diversification tends to be interwoven deeply with the process of internal adjustment in the business group. After moving their high-quality assets (or organizationally speaking, units) into listed affiliates, the business group will be faced with the problem of integrating the transferred units with those that are already there. Such a transferintegrate process should be understood both technologically and organizationally.

First, when we regard these transferred units as modular units with standard technological interfaces (e.g., input-output between vertical integrated units), such transfer-integrate procedures can be understood as cycles to rearrange those broken interlinks. Typically, one may find that an associated phenomenon, that is, the frequent and complicated Related Party Transactions (RPTs) between the listed affiliate and their connected parties during specific periods (Fisman and Wang, 2010; Peng et al., 2011), is considered to be a strategically controllable issue. Furthermore, the influence of reestablishing the broken technological interlinks will also vary to the extent to which listed affiliates have relied on transfer of units from the group to expand their business scope. However, on average, to unaffiliated firms that pursue a related diversification strategy, the constraints from such a transfer-integrate mechanism will be weak (i.e., when connected with former state-owned enterprises) or even nonexistent (i.e., when established as stand-alone firms).

More negative effects will be caused by organizational issues. When the resource is considered to be embedded organizationally in the units, it is difficult still to assume away the organizational aspect of the transfer-integrate procedure. The broken 
technological interlinks may be relatively easily reestablished, but the disturbed organizational interrelations tend not to be. Organizational interrelations are relevant to the sustainable advantages of business group and consist of the organizational foundation of related diversification benefit exertion; however, these are difficult to recover in a short period. Consequently, regardless of the occupation of the transferred units in the listed affiliates' business scope, there tends to be durable damage to the value-creation tendency of relatedness caused by the complexity of repairing organizational interrelation.

Drawing the two arguments together, the performance effect that group-affiliated listed firms can achieve from related diversification is systematically inferior to what their stand-alone counterparts can achieve.

H3: In the Chinese textile industry during the postreform era, group affiliation moderates the relationship between related diversification and firm performance in such a way that the relationship will be weaker for group-affiliated firms.

\section{MATERIALS AND METHODS}

Data: The sample initially includes 94 textile firms listed on either the Shanghai or Shenzhen Stock Exchange during the period 2001-2005. After eliminating firms that went public or were delisted during the period or have missing values, the final sample is a balanced panel dataset containing 62 firms and 310 firm-years. There are 46 group-affiliated firms (74\%) in the sample; this percentage is comparable with previous studies of Chinese business groups; for example, Ma et al. (2006) report a percentage of $67 \%$.

Accounting and financial data of listed firms are collected from the China Financial and Economic Research (CCFR) database and the Resset Financial Research database. Segment data (business description, sales, cost) are compiled from financial statements directly; we use the two-digit Chinese Industry Classification (CIC, version 2002) to code all segments and we compute diversification variables with segment sales data. Following, the textile industry refers to the broad industry sector consisting of several subindustries known as Textiles (CIC17), Apparel, footwear and caps (CIC18), Leather, fur, feather and related products (CIC19) and Chemical fibers (CIC28).

We use the yearbooks published annually by the National Bureau of Statistics of China (NBSC), Large Corporations of China, to obtain information on business groups such as registration name, address and turnover. Group affiliation is then identified by matching a listed firm's block shareholders with the business group by the name and other essential data that are reported in the CCFR database (and financial statements) and NBSC yearbooks.

Regression model: Regression models are specified in a hierarchical way. At first, to examine the effect of diversification on firm performance, we introduce the following regression model:

$\mathrm{P}_{\mathrm{it}}=\alpha_{0}+\alpha_{1} \mathrm{D}_{\mathrm{it}}+\alpha_{2} \mathrm{X}_{\mathrm{it}}+\mu_{\mathrm{it}}$

Where:

$\begin{array}{ll}\mathrm{i} & =1, \ldots, 62: \text { firm } \\ \mathrm{t} & =2001, \ldots, 2005: \text { time period } \\ \mathrm{P}_{\mathrm{it}} & =\text { Firm performance } \\ \mathrm{D}_{\mathrm{it}} & =\text { Diversification variables including the level } \\ & \quad \text { of unrelated diversification }\left(\mathrm{UDIV}_{\mathrm{it}}\right) \text { and } \\ & \quad \text { related diversification }\left(\mathrm{RDIV}_{\mathrm{it}}\right) \\ \mathrm{X}_{\mathrm{it}} & =\text { Control variables } \\ \mu_{\mathrm{it}} & =\end{array}$

Furthermore, to examine the differences in the diversification effects across group-affiliated firms and stand-alone firms, we propose the second regression model:

$P_{\text {it }}=\alpha_{0}+\alpha_{1} D_{\text {it }}+\alpha_{2} D_{\text {it }} \times G P_{i t}+\alpha_{3} G_{\text {it }}+\alpha_{4} X_{i t}+\mu_{\text {it }}$

Where:

$\mathrm{GP}_{\mathrm{it}} \quad=1$ if firm $\mathrm{i}$ is a group-affiliated firm, 0 otherwise

$\mathrm{D}_{\mathrm{it}} \times \mathrm{GP}_{\mathrm{it}}=$ The interaction terms between the dummy variable $\mathrm{GP}_{\mathrm{it}}$ and the diversification variables $\left(\mathrm{UDIV}_{\text {it }}\right.$ and $\left.\mathrm{RDIV}_{\mathrm{it}}\right)$

Diversification variables: The most important characteristics of the diversification pattern that a firm adopts include the type and level of diversification. We introduce a set of variables representing diversification accordingly. First, we introduce the rules to determine whether any two given segments are related to each other or not; after that, the entropy measure (e.g., Charumbira and Sunde, 2010; Lee et al., 2008) is used to calculate the level of the Unrelated Diversification $\left(\mathrm{UDIV}_{\mathrm{it}}\right)$ and Related Diversification $\left(\mathrm{RDIV}_{\mathrm{it}}\right)$.

The degree of unrelated diversification of firm $i$ in period t, UDIV it $_{\text {can }}$ be calculated as:

$\mathrm{UDIV}_{\mathrm{it}}=\sum_{\mathrm{g}=1}^{\mathrm{G}_{\mathrm{it}}}\left(\frac{\mathrm{S}_{\mathrm{g}, \mathrm{it}}}{\mathrm{TS}_{\mathrm{it}}}\right) \log \left(\frac{\mathrm{TS}_{\mathrm{it}}}{\mathrm{S}_{\mathrm{g}, \mathrm{it}}}\right)$ 
Where:

$\mathrm{g}=1, \ldots, \mathrm{G}$ ( $\mathrm{G}$ is the number of two-digit CIC industries in which the firm has business)

TS $=$ The firm's total sales

$\mathrm{S}_{\mathrm{g}}=$ The firm's sales in industry $\mathrm{g}$

Then, let us consider the case in which the textile firm has pursued diversification into related subindustries in the textile industry. The degree of related diversification of firm $\mathrm{i}$ in period $\mathrm{t}, \mathrm{RDIV}_{\mathrm{it}}$, can be computed as follows:

$\operatorname{RDIV}_{\mathrm{it}}=\sum_{\mathrm{k}=1}^{\mathrm{K}_{\mathrm{it}}}\left(\frac{\mathrm{m}_{\mathrm{k}, \mathrm{it}}}{\mathrm{TS}_{\mathrm{it}}}\right) \log \left(\frac{\mathrm{M}_{\mathrm{it}}}{\mathrm{m}_{\mathrm{k}, \mathrm{it}}}\right)$

Where:

$\mathrm{k}=1, \ldots, \mathrm{K}$ ( $\mathrm{K}$ is the number of subindustries of the textile industry in which the firm does business)

$\mathrm{M}=$ The firm's total sales in the textile industry

$\mathrm{m}_{\mathrm{k}}=$ The firm's sales in subindustry $\mathrm{k}$

Construction of the variable of Related Diversification $\left(\mathrm{RDIV}_{\mathrm{it}}\right)$ assumes that the textile firms have not significantly pursued related diversification in other industries. Given the general trend of the sample firms being relatively specialized in the textile industry (we have calculated the specialization ratio as the ratio of sales in the textile industry to total sales for all firm-years in the sample and the mean value of the specialization ratio is 0.88 ), such a simplification is reasonable.

Dependent variables: We use Tobin's Q and ROA as dependent variables $P_{i t}$ in our regression analyses. Tobin's Q and ROA have been employed in the literature as measures of firm performance (Fukui and Ushijima, 2007; Khanna and Palepu, 2000).

Tobin's Q is a widely used measure of firm value in the finance discipline. As in previous studies of business groups (e.g., Khanna and Palepu, 2000), a simplified version of $\mathrm{Q}$ can be calculated as:

Tobin's Q = (Market value of equity+Book value of total debt)/Book value of total assets

It is well known that in the Chinese stock market, a significant proportion of the shares were non-publicly tradable shares before 2007 when China completed the 'share structure resolution reform' to allow nontradable shares to be publicly tradable (Peng et al., 2011). As it is difficult to estimate the prices of these non-publicly tradable shares, we use the price of publicly tradable shares (Huang and Song, 2006).

ROA is employed to measure the short-term profitability of the firm, which is defined as:

ROA $=($ Net income + Interest $\times(1-$ Tax rate $)) /$ Total assets

Following Khanna and Palepu (2000), we take into consideration the tax-shield effects of debt structure and interest paid. As argued in Huang and Song (2006), Chinese companies are subject to different income tax rates based on the district where they operate, the period when they were established and the composition of ownership. Accordingly, we calculate an average tax rate for each firm.

Control variables: Several widely employed control variables are included. First, the leverage ratio (LEV) is computed as debts divided by total assets, to assess the extent to which listed firms may rely less on their internal capital markets when access to external financial resources is possible (Lins and Servaes, 2002). Second, the logarithm of total sales (SIZE) is used to control for the size effect (Lee et al., 2008). Finally, the sales growth rate (GROWTH) is controlled for (Fukui and Ushijima, 2007).

\section{RESULTS AND DISCUSSION}

Descriptive statistics: Table 1 presents the means and standard deviations of all continuous variables for both the full sample and for group-affiliated firms and standalone firms separately. First, consider the statistics for the full sample. The mean of Tobin's Q is 1.888, which is higher than those reported in studies of listed firms in developed economies (e.g., Fukui and Ushijima, 2007) but acceptable when taking into consideration the characteristics of the Chinese stock market as a representative emerging market (Huang and Song, 2006). The average levels of unrelated and related diversification are relatively low, 0.238 and 0.327 respectively; generally, the textile firms in the sample are still in the early stages of business expansion. We then compare the means between group-affiliated firms and stand-alone firms to explore differences in firm performances and strategy patterns. Compared with stand-alone firms, group-affiliated firms perform worse on the stock market (Tobin's Q), whereas they achieve better profitability (ROA). 
Am. J. of Economics and Business Administration 3 (2): 234-246, 2011

Table 1: Descriptive statistics ${ }^{\mathrm{a}}$

\begin{tabular}{|c|c|c|c|c|c|c|c|}
\hline & & \multicolumn{2}{|c|}{$\begin{array}{l}\text { Full sample } \\
(\mathrm{n}=310)\end{array}$} & \multicolumn{2}{|c|}{$\begin{array}{l}\text { Group-affilated } \\
\text { firms }(n=230)\end{array}$} & \multicolumn{2}{|c|}{$\begin{array}{l}\text { Stand-alone } \\
\text { firms }(\mathrm{n}=80)\end{array}$} \\
\hline & & Mean & SD & Mean & SD & Mean & SD \\
\hline Tobin's Q & (market value of equity+total debt)/total assets & 1.888 & 1.015 & 1.769 & 0.850 & 2.230 & 1.333 \\
\hline ROA & Return on assets & 0.014 & 0.076 & 0.017 & 0.077 & 0.006 & 0.074 \\
\hline UDIV & Level of unrelated diversification & 0.238 & 0.290 & 0.242 & 0.294 & 0.228 & 0.278 \\
\hline RDIV & Level of related diversification & 0.327 & 0.327 & 0.356 & 0.343 & 0.243 & 0.259 \\
\hline LEV & Debt to total assets & 0.517 & 0.190 & 0.512 & 0.196 & 0.532 & 0.169 \\
\hline SIZE & Log of total sales & 20.523 & 0.973 & 20.722 & 0.882 & 19.951 & 1.000 \\
\hline GROWTH & Growth rate in sales & 0.145 & 0.313 & 0.168 & 0.328 & 0.079 & 0.256 \\
\hline
\end{tabular}

${ }^{\mathrm{a}} \mathrm{n}$ is sample size

Table 2: Correlation matrix ${ }^{\mathrm{a}}$

\begin{tabular}{llrllll}
\hline Variables & 1 & 2 & 3 & 4 & 5 & 6 \\
\hline 1. Tobin's Q & 1 & & & & & \\
2. ROA & -0.036 & \multicolumn{1}{l}{1} & & & & \\
3. UDIV & -0.083 & -0.067 & 1 & & & \\
4. RDIV & -0.117 & 0.063 & -0.086 & 1 & & \\
5. LEV & -0.188 & -0.321 & 0.246 & 0.110 & 1 & \\
6. SIZE & -0.497 & 0.222 & 0.012 & 0.387 & 0.005 & 1 \\
7. GROWTH & -0.033 & 0.275 & -0.023 & 0.130 & 0.026 & 0.239 \\
\hline a : Full sample (n $=310)$ & & & & &
\end{tabular}

Furthermore, they are more diversified (both UDIV and RDIV), with less debt in their capital structures (LEV), are larger in size (SIZE) and are growing faster (GROWTH). Table 2 reports the correlation coefficients for the full sample. One interesting point is that the correlation is -0.036 between Tobin's Q and ROA. Such a negative correlation has also been reported in recent studies of Chinese listed firms (e.g., Yuan et al., 2008). This may imply the existence of an overall inconsistency between the long-period and short-period goals/strategies for the listed firms in the sample.

Regression results: The regression results are presented in Table 3. We use standard panel regression techniques as our estimation method, accounting in all regressions for unobservable fixed firm-specific and firm-invariant time-specific effects. According to the Hausman specification test, random effects are rejected in favor of fixed effects estimations in all regressions; therefore, we report only the results of the fixed effects model. To avoid the possible reverse causality between diversification and firm performance, we lag all diversification variables one period. The adjusted $\mathrm{R}^{2}$ of all regressions in Table 3 exceeds 0.48 , revealing the reasonably high explanatory power of the models.

Models I and II estimate the effects of unrelated and related diversification on firm value (Tobin's Q) and profitability (ROA). In models III and IV, the group affiliation dummy variable GP and the interaction terms between it and the diversification variables are added to compare the diversification effects between groupaffiliated firms and their stand-alone counterparts. As the dummy variable GP is time invariant, the effect of GP is fully absorbed by the firm-specific effects in the fixed-effects models and is therefore unidentifiable.

With respect to the control variables, the results are comparable with previous studies of listed firms in developed economies and some studies on Chinese firms. In models II and IV, which estimate firm performance as a measure of profitability (ROA), the coefficient for the leverage ratio variable LEV is significantly negative and consistent with previous studies (e.g., Ma et al., 2006); in models I and III, although insignificant, the coefficient for LEV is still negative as reported in Fukui and Ushijima (2007). All these results imply that the high leverage ratio tends to constrain the overall outcome of the strategies that the firm can perform. The effect of sales growth (GROWTH) is positive but not significant in models I and III; the coefficients for the variable SIZE are insignificant except in model IV.

Hypothesis 1 suggests that unrelated diversification will be related positively to firm performance. As shown in model I, the coefficient of unrelated diversification is positive and significant, suggesting that unrelated diversification has a positive effect on long-term firm performance (Tobin's Q). Meanwhile, the effect of unrelated diversification on profitability (ROA) is significantly negative. It might be noted that although we have expected a positive effect of unrelated diversification on firm performance, the assumed positive causal relationship may change to be insignificant or even negative when we use short-term performance measures (such as profitability) because of the long-period tendency of unrelated diversification in value creation (Kim et al., 2004b). The result in model II may reveal this tendency. Drawing on the theoretical predictions of institution-based studies of diversification in emerging economies, we can therefore say that the findings support Hypothesis 1.

Models III and IV present the results of regressions estimating the impacts of group affiliation on the relationship between diversification and performance. 
Am. J. of Economics and Business Administration 3 (2): 234-246, 2011

Table 3: The effects of diversification on firm performance ${ }^{\mathrm{a}}$

\begin{tabular}{lllll}
\hline Dependent variable & I (Tobin's Q) & II (ROA) & III (Tobin’s Q) & IV (ROA) \\
\hline UDIV & $0.576^{* *}(0.229)$ & $-0.047^{*}(0.026)$ & $0.156(0.335)$ & $-0.038(0.039)$ \\
RDIV & $-0.023(0.226)$ & $-0.010(0.026)$ & $1.153^{* *}(0.472)$ & $0.097^{*}(0.055)$ \\
UDIV×GP & & & $0.741^{*}(0.405)$ & $-0.009(0.047)$ \\
RDIV $\times$ GP & & $-1.505^{* * *}(0.526)$ & $-0.135^{* *}(0.061)$ \\
LEV & $-0.267(0.339)$ & $-0.127^{* * *}(0.039)$ & $-0.214(0.331)$ & $-0.126^{* * *}(0.039)$ \\
SIZE & $-0.094(0.136)$ & $0.025(0.016)$ & $-0.068(0.133)$ & $0.029^{*}(0.016)$ \\
GROWTH & $0.023(0.109)$ & $0.024^{*}(0.012)$ & $0.021(0.106)$ & $0.023^{*}(0.012)$ \\
Firm effect & Yes & Yes & Yes & Yes \\
Time effect & Yes & Yes & Yes & Yes \\
Adjusted $\mathrm{R}^{2}$ & 0.780 & 0.488 & 0.790 & 0.494 \\
${ }^{\mathrm{a}}: \mathrm{n}=310 . .^{* * *}: \mathrm{p}<0.01 ; * *: \mathrm{p}<0.05 ; *: \mathrm{p}<0.1$. Standard errors are in parentheses. All estimations are those of fixed-effects model
\end{tabular}

Hypothesis 2 predicts that group affiliation does not affect the relationship between unrelated diversification and firm performance. Contrary to our expectations, the coefficient of the interaction term between unrelated diversification and group affiliation in model III is positive but marginally significant at the $10 \%$ significance level, suggesting that group-affiliated firms still possess a weak advantage in pursuing unrelated diversification over their stand-alone counterparts; thus, Hypothesis 2 is not supported.

In Hypothesis 3, we assert that group affiliation affects the relationship between related diversification and firm performance significantly in such a way that the related diversification performance of group-affiliated firms worsens. Consistent with our expectation, the coefficients of the interaction term between related diversification and group affiliation are all positive and significant in the two models (both Tobin's Q and ROA). Affiliated firms' related diversification performance is worse than that of their stand-alone counterparts; thus, Hypothesis 3 is supported.

Discussions, implications and limitations: From an institution-based view, this study tries to deepen the understanding of the effects of institutional transitions and resulting organizational evolution of business groups on the diversification-performance link of group-affiliated firms in emerging Asian economies. In contrast with previous studies that separately examine the role of group internal organization (e.g., organizational structure and internal power dependency) and the impact of the institutional transition, we argue the possibility that business groups exert efforts to change their internal organization that avoidably have an impact on the diversification effect that affiliated firms can achieve.

To explore the influence of such an institutionally rooted organizational evolution, one needs to design the institutional settings carefully. We accomplish this goal by setting the institutional background to be the postreform era of China, which is known as a characteristic model of emerging Asian economies undergoing gradual institutional transition (Carney, 2008). Furthermore, we focus on the unique relationship between Chinese business groups and their listed affiliates to address the organizational evolution of the business groups after their partial listing (Meyer and Lu, 2005).

In the context of evolution after partial listing, we propose a set of hypotheses to explore the dominant influence of institutional environments and the active role of Chinese business groups' organizational evolution in determining the outcomes from affiliated firms' diversification. We then test the hypotheses using the 2001-2005 data on listed firms from the Chinese textile industry.

The institution-based theory of diversification argues about the dominant influence of institutional environments on the diversification-performance relationship in emerging economies. Specifically, in the Chinese emerging economy during its postreform era after 2000, it is predicted that there should be a homogeneous tendency in the diversification effects across different business organizational forms; specifically, unrelated diversification affects firm performance positively no matter whether the firm is affiliated to a business group or not. Our findings about the relationship between unrelated diversification and performance do lend support to this prediction. That is, at late stages of the institutional transition in China, the dominant characteristic of institutional environments is still the existence of institutional imperfection, which legitimates business group internal capital markets to facilitate affiliated firms' unrelated diversification.

In contrast with the argument about the dominant influence of institutional environments, which relies heavily on resource-based views (Barney et al., 2001), we adopt organizational and evolutionary perspectives to address the active role of Chinese business groups' evolution during the postreform era. We develop the arguments in Meyer and Lu (2005) to address explicitly the long-run tendency of the evolution of Chinese 
business groups after their partial listing. Furthermore, we identify the two kinds of strategies among which the institutional strategy is considered to be the fundamental factor toward sustainable advantages and the elementary 'transfer-integrate' procedure during the evolutionary process. Both unrelated diversification and related diversification are involved in the evolution cycles but follow different mechanisms.

Both institution-based studies of business groups and the organizational evolution view assert a decreasing trend in the performance effect when affiliated firms conduct unrelated diversification at late stages of institutional transition. The evolution of business groups may ease such a decreasing tendency; however, the possibility depends on the extent to which business groups have evolved successfully. Considering the strategic and organizational complexity, we have assumed that affiliated firms will not perform better than their stand-alone counterparts. Our evidence shows a positive, although marginally significant, impact of group affiliation on the effect of unrelated diversification. A possible explanation may be that the business groups in the sample have renewed their internal organization relatively efficiently, which makes their internal markets superior. However, given the marginal significance of the effect, we instead emphasize the importance of the autonomous evolution of business groups when discussing the causal relationship between business groups' internal markets and the (unrelated) diversification effect of their affiliated firms.

Compared with unrelated diversification, related diversification tends to be interwoven with the internal adjustments during the evolutionary process more directly and deeply. We address this issue by drawing on a different understanding of the transfer-integrate procedure as a simple change in the technological interlinks between modular units inside the group and complicated restructuring of organizational interlinks inside the group. Drawing the two arguments together, group-affiliated firms tend to perform related diversification worse than their stand-alone counterparts. The empirical results support our proposition. This result in turn helps to address the difficulty in pursuing unrelated diversification as the evolution will determine the organizational foundation of the business groups' internal markets.

In conclusion, our analysis contributes to the institution-based study of diversification and business groups in emerging economies. First, we developed arguments from previous studies to incorporate evolutionary perspectives and established an integrated framework to analyze the organizational dynamics of business groups in response to changes in institutional environments. On the basis of this holistic approach, we were able to discuss the strategic complexity in groupaffiliated firms' diversification; otherwise, influences from the organizational and institutional constraints during the business group's evolution would be difficult to account for. Although our institutional setting is China's emerging economy during its postreform era, researchers would find that the analysis framework developed in the study can be used in other emerging economies undergoing fundamental institutional transitions where business groups play significant roles and evolve organizationally.

Inevitably, this study has several limitations and we leave them for future research. First, we relied heavily on issues such as relatedness and vertical integration for addressing the diversification effect, but we have not investigated how the relevant mechanisms work during business groups' evolution. Future research could extend this study by adding variables of relatedness and vertical integration to the model directly (Farjoun, 1998). Second, in the current study, we assumed the existence of a systematic coevolutionary relationship between business groups and the institutional environments, which allows us to identify the stage of institutional transition for a specific institutional setting. This simplification tends to underestimate the strategic complexity of business groups' evolution in a changing environment. In future research, researchers may consider using historical study (e.g., Kim et al., 2004b; Narula and Upadhyay, 2010) to delineate the comprehensive interactions between environments and business groups.

\section{CONCLUSION}

This study investigated the influence of institutional changes and the active role of business groups' organizational evolution in determining the strategy space of diversification and the performance effect that affiliated firms can achieve. Focusing on the phenomenon of Chinese business groups' evolution after partial listing, we institutionally analyzed the diversification-performance relationship of groupaffiliated firms during China's postreform era. The results suggest that the dominant influence of institutional environments exists and leads to a homogenous trend in the diversification effect; that is, unrelated diversification positively affects performance of all firms in the sample. When considering the differences in the effect of diversification, the results suggest that affiliated firms still possess a weak advantage over their stand-alone counterparts; at the same time, it is found that affiliated firms perform worse when pursuing related diversification. 
These findings therefore contribute to improving our understanding of the strategic complexity when business groups evolve organizationally with changing institutional environments and its implications for the diversification-performance link of affiliated firms. That is, even at late stages of the institutional transition: (1) it is still possible for the affiliated firm to achieve performance advantages from unrelated diversification, therefore implying a potential contribution of such an organizational evolution to the comparative strength of business groups' internal markets; (2) however, the simultaneous existence of poor outcomes from related diversification suggests that organizational evolution may unavoidably lead to disruptions to the internal technological and organizational interrelations, which are known as the fundamental foundations for the realization of related diversification's value-creation tendency.

\section{REFERENCES}

Aivazian, V.A., Y. Ge and J. Qiu, 2005. Can corporatization improve the performance of stateowned enterprises even without privatization? J. Corporate Finance, 11: 791-808. DOI: 10.1016/j.jcorpfin.2004.11.001

Barney, J.B., M. Wright and D.J. Ketchen Jr, 2001. The resource-based view of the firm: Ten years after 1991. J. Manag., 27: 625-641. DOI: $10.1177 / 014920630102700601$

Carney, M., 2008. The many futures of Asian business groups. Asia Pacific J. Manag., 25: 595-613. DOI: 10.1007/s10490-008-9092-5

Carney, M., D. Shapiro and Y. Tang, 2009. Business group performance in China: Ownership and temporal considerations. Manag. Organ. Rev., 5: 167-193. DOI: 10.1111/j.1740-8784.2009.00139.x

Chakrabarti, A., K. Singh and I. Mahmood, 2007. Diversification and performance: Evidence from East Asian firms. Strategic Manag. J., 28: 101-120. DOI: $10.1002 / \mathrm{smj} .572$

Chandler, A.D., 1962. Strategy and Structure: Chapters in the History of the American Industrial Enterprise. 1st Edn., Beard Books, USA., ISBN10: 9781587981982, pp: 480.

Chang, S.J., 2006. Business groups in East Asia: Postcrisis restructuring and new growth. Asia Pacific J. Manag., 23: 407-417. DOI: 10.1007/s10490-006-9013-4

Chang, S.J. and U. Choi, 1988. Strategy, structure and performance of Korean business groups: A transactions cost approach. J. Ind. Econ., 37: 141-158.

Chang, S.J. and J. Hong, 2000. Economic performance of group-affiliated companies in Korea: Intragroup resource sharing and internal business transactions. Academy Manag. J., 43: 429-448. DOI: $10.2307 / 1556403$
Charumbira, M. and T. Sunde, 2010. Seller concentration in the grain milling industry. Am. J. Econ. Bus. Admin., 2: 247-252. DOI: 10.3844/ajebasp.2010.247.252

Farjoun, M., 1998. The independent and joint effects of the skill and physical bases of relatedness in diversification. Strategic Manag. J., 19: 611-630. DOI: 10.1002/(SICI)10970266(199807)19:7<611::AID-SMJ962>3.3.CO;2-5

Fisman, R. and Y. Wang. 2010. Trading favors within Chinese business groups. Am. Econ. Rev., 100: 429-433. DOI: 10.1257/aer.100.2.429

Fukui, Y. and T. Ushijima, 2007. Corporate diversification, performance, and restructuring in the largest Japanese manufacturers. J. Japanese Int. Econ., 21 : 303-323. 10.1016/j.jjie.2006.06.002

Granovetter, M., 1995. Coase revisited: Business groups in the modern economy. Ind. Corporate Change, 4: 93-130. DOI: 10.1093/icc/4.1.93

Huang, G. and F.M. Song, 2006. The determinants of capital structure: Evidence from China. China Economic Rev., 17: 14-36. $\quad$ DOI: 10.1016/j.chieco.2005.02.007

Kedia, B.L., D. Mukherjee and S. Lahiri, 2006. Indian business groups: Evolution and transformation. Asia Pacific J. Manag., 23: 559-577. DOI: 10.1007/s10490-006-9020-5

Khanna, T. and K. Palepu, 2000. Is group affiliation profitable in emerging markets? An analysis of diversified Indian business groups. J. Finance, 55: 867-891. DOI: 10.1111/0022-1082.00229

Khanna, T. and Y. Yafeh, 2007. Business groups in emerging markets: Paragons or parasites? J. Econ. Liter., 45: 331-372. DOI: 10.1257/jel.45.2.331

Kim, H., R.E. Hoskisson and W.P. Wan, 2004a. Power dependence, diversification strategy, and performance in keiretsu member firms. Strat. Manag. J., 25: 613-636. DOI: 10.1002/smj.395

Kim, H., R.E. Hoskisson, L. Tihanyi and J. Hong, 2004b. The evolution and restructuring of diversified business groups in emerging markets: The lessons from chaebols in Korea. Asia Pacific J. Manag., $\quad 21$ : 25-48. 10.1023/B:APJM.0000024076.86696.d5

Lee, K., M.W. Peng and K. Lee, 2008. From diversification premium to diversification discount during institutional transitions. J. World Bus., 43: 47-65. DOI: 10.1016/j.jwb.2007.10.010

Lin, C. and D. Su, 2008. Industrial diversification, partial privatization and firm valuation: Evidence from publicly listed firms in China. J. Corporate Finance, $\quad 14$ : 405-417. DOI: 10.1016/j.jcorpfin.2008.05.001 
Lins, K.V. and H. Servaes, 2002. Is corporate diversification beneficial in emerging markets? Financ. Manag., 31: 5-31.

Lu, Y. and J. Yao, 2006. Impact of state ownership and control mechanisms on the performance of group affiliated companies in China. Asia Pacific J. Manag., 23: 485-503. DOI: 10.1007/s10490-006-9017-0

Ma, X., X. Yao and Y. Xi, 2006. Business group affiliation and firm performance in a transition economy: A focus on ownership voids. Asia Pacific J. Manag., 23: 467-483. DOI: 10.1007/s10490-006-9011-6

Meyer, M.W. and X. Lu, 2005. Managing indefinite boundaries: The strategy and structure of a Chinese business firm. Manag. Organ. Rev., 1: 57-86. DOI: 10.1111/j.1740-8784.2004.00004.x

Narula, S.A. and K.M. Upadhyay, 2010. Strategy in turbulent environment: A case study of Indian domestic company. Am. J. Econ. Bus. Admin., 2: 160-168. DOI: 10.3844/ajebasp.2010.160.168

Peng, M.W., 2003. Institutional transitions and strategic choices. Acad. Manag. Rev., 28: 275-296. DOI: $10.2307 / 30040713$
Peng, W.Q., K.C.J. Wei and Z. Yang, 2011. in press. Tunneling or propping: Evidence from connected transactions in China. J. Corporate Finance, 17: 306-325. DOI: 10.1016/j.jcorpfin.2010.08.002

Rumelt, R.P., 1986. Strategy, Structure and Economic Performance. 1st Edn., Harvard University Press, Boston, ISBN-10: 0875841260, pp: 235.

Singh, M., A. Nejadmalayeri and I. Mathur, 2007. Performance impact of business group affiliation: An analysis of the diversification-performance link in a developing economy. J. Bus. Res., 60: 339-347. DOI: 10.1016/j.jbusres.2006.10.024

Williamson, O.E., 1983. Markets and Hierarchies: Analysis and Antitrust Implications: A Study in the Economics of Internal Organization. 1st Edn., Free Press, New York, ISBN-10: 0029347807, pp: 286.

Yuan, R., J.Z. Xiao and H. Zou, 2008. Mutual funds' ownership and firm performance: Evidence from China. J. Banking Finance, 32: 1552-1565. DOI: 10.1016/j.jbankfin.2007.08.001 